Bartosz Nowakowski

\title{
Kompetencje organu administracji publicznej w zakresie zatwierdzania regulaminu strzelnicy. Propozycje zmian de lege ferenda
}

Competence of the public administration authority regarding the approval of shooting range regulations. Proposals for de lege ferenda changes

\footnotetext{
This disputable issue was regulated in the provisions of the Act on Arms and Ammunition. The article contains numerous references to the jurisprudence of the Supreme Administrative Court and provincial (voivodeship) administrative courts. The author presented the administrative solutions to this issue and presented controversial and doubtful regulations. The presented delege ferenda conclusions are aimed at introducing a precise and compatible procedure for approving shooting range regulations by the head of a commune, mayor or president of a city, in order to eliminate discretion in this respect.
}

Keywords: administrative proceedings, administrative court, shooting range

Dyskusyjna kwestia została uregulowana w przepisach ustawy o broni i amunicji. Artykuł zawiera liczne odniesienia do orzecznictwa Naczelnego Sądu Administracyjnego oraz wojewódzkich sądów administracyjnych. Przedstawia obowiązujące rozwiązania administracyjne w tej materii oraz prezentuje regulacje dyskusyjne i budzące wątpliwości. Przedstawione wnioski de lege ferenda idą w kierunku wprowadzenia precyzyjnej i kompatybilnej procedury zatwierdzenia regulaminu strzelnicy przez wójta, burmistrza czy prezydenta miasta, aby wyeliminować uznaniowość w tym zakresie.

Słowa kluczowe: postępowanie administracyjne, sąd administracyjny, strzelnica

Doktor hab. nauk prawnych, profesor uczelni Uniwersytet Przyrodniczo-Humanistyczny w Siedlcach, Wydział Nauk Społecznych, Instytut Nauk o Polityce i Administracji, SIEDLCE, POLSKA • bartosz.nowakowski@uph.edu.pl • https://orcid.org/0000-0002-7182-4600

\section{Wprowadzenie}

Pod koniec roku 2018 ówczesny wiceminister obrony narodowej Michał Dworczyk na konferencji „Sokół - strzelnica w powiecie”, która odbyła się w dniach 9-10 grudnia 2018 r., zapowiedział realizację programu „Strzelnica w powiecie”. Inicjatywa zakładała dofinansowanie przez MON budowy i rewitalizacji strzelnic w Polsce. Skierowana została do jednostek samorządu terytorialnego i organizacji pozarządowych ${ }^{1}$. Była ona kontynuacją ogłoszonego 16 kwietnia $2018 \mathrm{r}$.

1 Zob. szerzej na ten temat: http://strzelnicawpowiecie.pl/ [dostęp 7 stycznia 2020 r.]; J. Lewandowski, Sokół - strzelnica w powiecie, Strzał.pl 1/2018, s. 92-95. Ponadto wy- 
na stronach Rządowego Centrum Legislacji projektu rozporządzenia Ministra Obrony Narodowej w sprawie zakresu, sposobu i trybu dofinansowania z budżetu państwa zadań związanych z budową, remontami i utrzymaniem strzelnic oraz rozwijaniem sportu strzeleckiego w szczególności wśród dzieci i młodzieży oraz organizacji proobronnych, objętych dofinansowaniem z budżetu państwa, a także określała sposób i tryb udzielania dotacji na te zadania ${ }^{2}$. Pomijając w niniejszym artykule niezwykle ważki aspekt znaczenia obronnego i sportowego wspomnianej inicjatywy, na szczególną uwagę zasługuje próba zintegrowania działań administracji rządowej, samorządowej oraz oddolnych, tzn. społecznych, inicjatyw obywatelskich. Projekt tym bardziej cenny, że na gruncie styku tych trzech sektorów nie zawsze dochodzi do jednolitej wizji postrzegania działań mających swoje źródło w polityce państwa. Ostatecznie zróżnicowane próby przedmiotowych rozwiązań znajdują swoje odzwierciedlenie w orzecznictwie sądów administracyjnych lub w konieczności nowelizacji ustawodawstwa. Taka sytuacja - od pewnego czasu - ma miejsce w odniesieniu do jednego z aspektów powstawania strzelnic, a mianowicie procedury administracyjnej $\mathrm{w}$ zatwierdzaniu ich regulaminu.

Jak zauważył poseł Jarosław Stawiarski w interpelacji z 9 lutego 2017 r. skierowanej do Ministra Spraw Wewnętrznych i Administracji (dalej: MSWiA), osoby zamierzające zorganizować strzelnicę napotykają w praktyce liczne trudności. Często polegają one na odmowie ze strony wójtów (burmistrzów i prezydentów miast) zatwierdzenia regulaminu strzelnicy oraz żądaniu przedstawienia bądź uzyskania decyzji o dopuszczeniu strzelnicy do użytkowania. Można domniemywać, wskazuje autor interpelacji, że zazwyczaj trudności te nie wynikają ze złej woli organów wykonawczych gmin, ale są spowodowane niejasnością i brakiem komplementarności obowiązujących przepisów ${ }^{3}$.

stąpienie wiceministra MON Michała Dworczyka: https://www.youtube.com/playlist ?list=PLnkYgipjfYdbrd21gsemsiV3Yq6ShTmW8 [dostęp 7 stycznia 2020 r.]. Zob. także A. Turczyn, MON ogłasza konkurs pn. „Strzelnica w powiecie” na dofinansowanie zadań związanych z budowa lub remontem strzelnic, https://trybun.org.pl/2018/08/30/ mon-oglasza-konkurs-pn-strzelnica-w-powiecie-na-dofinansowanie-zadan-zwiazanych-z-budowa-lub-remontem-strzelnic/ [dostęp 7 stycznia 2020 r.].

2 Zob. A. Turczyn, Projekt rozporządzenia MON w sprawie dofinansowania $z$ budżetu państwa zadań zwiąanych $z$ budowa, remontami $i$ utrzymaniem strzelnic oraz rozwijaniem sportu strzeleckiego, https://trybun.org.pl/2018/04/18/projekt-rozporzadzenia-mon-w-sprawie-dofinansowania-z-budzetu-panstwa-zadan-zwiazanych-z-budowa-remontami-i-utrzymaniem-strzelnic-oraz-rozwijaniem-sportu-strzeleckiego/ [dostęp 7 stycznia 2020 r.].

3 Zob. J. Stawiarski, Interpelacja nr 10011 do ministra spraw wewnętrznych i administracji w sprawie wzorcowego regulaminu strzelnic, 9 lutego 2017 r., http://www.sejm.gov. pl/Sejm8.nsf/InterpelacjaTresc.xsp?key=13829D7B [dostęp 7 stycznia 2020 r.]. 


\section{Zakres kompetencji wójta (burmistrza, prezydenta miasta) w zatwierdzaniu regulaminu strzelnicy}

Na podstawie art. 47 ustawy o broni i amunicji ${ }^{4}$ regulamin strzelnicy podlega zatwierdzeniu przez wójta, (burmistrza, prezydenta miasta) właściwego ze względu na lokalizację tego obiektu i następuje w drodze decyzji administracyjnej. Jak podkreśla S. Maj, prowadzący strzelnicę opracowuje projekt regulaminu strzelnicy i przedkłada go wraz z wnioskiem do organu zatwierdzającego wydającego decyzję. Wraz z wnioskiem składa dowód uiszczenia opłaty skarbowej ${ }^{6}$. Natomiast od decyzji właściwego organu przysługuje odwołanie do samorządowego kolegium odwoławczego (art. 17 Kodeksu postępowania administracyjnego) ${ }^{7}$. Warto podkreślić, że nałożony przez ustawodawcę na właściciela lub zarządcę strzelnicy obowiązek opracowania regulaminu obiektu daje możliwość uszczegółowienia lub określenia dodatkowych wymogów i zasad bezpieczeństwa. Nie mogą one jednak być niezgodne z rozporządzeniem Ministra Spraw Wewnętrznych i Administracji z 20 marca 2000 r. dotyczącym wzorcowego regulaminu strzelnic ${ }^{8}$, a kwestie owej zgodności bada organ administracji samorządowej i w zależności od rezultatu weryfikacji podejmuje decyzję aprobującą lub odmowną.

W kontekście przeprowadzonej analizy warto podkreślić fakt, że przywołana obowiązująca regulacja prawna została wprowadzona nowelizacją z 10 lipca 2003 r. ${ }^{9}$. Prawodawca w kompetencji organu administracji samorządowej pozostawił wyłącznie zatwierdzenie regulaminu strzelnicy, odstępując od wcześniejszego obowiązku dodatkowego dopuszczenia do jej użytkowania. Oznacza to, zdaniem Joanny Majo, że wójt (burmistrz, prezydent miasta), któremu przedstawiono do zatwierdzenia regulamin strzelnicy, nie jest uprawniony do badania innych kwestii niż jedynie treść regulaminu. Jego rola została ograniczona do oceny tego regulaminu $\mathrm{z}$ punktu widzenia zgodności z wzorcem normatywnym określonym w rozporządzeniu MSWiA z 15 marca 2000 r. w sprawie wzorcowe-

Ustawa z 21 maja 1999 r. o broni i amunicji, Dz.U. nr 53, poz. 549; dalej także u.o.b.a.

$5 \quad$ Zob. B. Barszczewska, Regulamin strzelnicy musi być zatwierdzony przez wójta, Prawo. pl, 18 października 2016 r., https://www.prawo.pl/samorzad/regulamin-strzelnicy-musi-byc-zatwierdzony-przez-wojta,106908.html [dostęp 7 stycznia 2020 r.].

6 Ustawa z 9 września 2000 r. o podatku od czynności cywilnoprawnych, Dz.U. nr 86, poz. 959, art. 15; S. Maj, Ustawa o broni i amunicji. Komentarz, art. 47, LEX nr 16836326.

7 Zob. także S. Maj, Ustawa o broni i amunicji, op. cit.

8 Rozporządzenie MSWiA z 15 marca 2000 r. w sprawie wzorcowego regulaminu strzelnic, Dz.U. nr 18, poz. 234. Zob. H. Kowalik, Aspekty formalne projektu „Strzelnica w powiecie" [w] Obrona Narodowa, Sokót - Strzelnica w powiecie. Publikacja po konferencji 9-10 grudnia 2017 w Warszawie, Warszawa 2017, s. 29.

9 Art. 47 zmieniony przez art. 5 ustawy z 27 marca 2003 r. o zmianie ustawy - Prawo budowlane oraz o zmianie niektórych ustaw, Dz.U. nr 80, poz. 718, z dniem 11 lipca $2003 \mathrm{r}$. 
go regulaminu strzelnic, a więc pod kątem przyjęcia odpowiednich rozwiązań dotyczących sposobu korzystania ze strzelnicy i obchodzenia się na niej z bronią. Poza kompetencjami wójta (burmistrza, prezydenta miasta) pozostaje więc weryfikowanie pozostałych dokumentów związanych ze strzelnicą, wymaganych przez inne niż ustawa o broni i amunicji przepisy, w tym prawa budowlanego, zagospodarowania przestrzennego czy ochrony środowiska. W konsekwencji kwestie położenia strzelnicy czy poziomu hałasu powstającego podczas jej użytkowania są oddzielnym zagadnieniem, które nie podlega weryfikacji w toku postępowania o zatwierdzenie regulaminu strzelnicy. Te sprawy - jako wynikające z przepisów odrębnych - podlegają rozpatrzeniu w trybie i na zasadach określonych $\mathrm{w}$ tychże przepisach, a nie w postępowaniu prowadzonym na podstawie ustawy o broni i amunicji ${ }^{10}$. Jakiekolwiek działania wójta (burmistrza, prezydenta miasta) wykraczające poza ten zakres stanowią przekroczenie własnych kompetencji.

Analogiczny pogląd wyraził A. Turczyn, według którego z przepisów prawa nie wynika, by decyzja w sprawie zatwierdzenia regulaminu strzelnicy była aktem finalnym, kończącym i niejako podsumowującym z punktu widzenia zgodności z prawem cały proces organizowania strzelnicy, a w konsekwencji stanowiącym wyłączną podstawę przystąpienia do jej legalnego użytkowania, co zbliżałoby tę decyzję w swej konstrukcji do sui qeneris zezwolenia na prowadzenie strzelnicy. Przeciwnie, sam fakt zatwierdzenia regulaminu strzelnicy jako zgodnego z wzorcem określonym w rozporządzeniu z 15 marca 2000 r., wcale nie przesądza, że strzelnica spełnia wszystkie określone prawem w danych okolicznościach faktycznych wymogi, a zatem, że będzie funkcjonować legalnie. Ocena dokonywana przez wójta (burmistrza, prezydenta miasta) na podstawie art. 47 u.o.b.a. w związku z $\$ 1$ rozporządzenia MSWiA w sprawie wzorcowego regulaminu strzelnic zgodnie $\mathrm{z}$ literalnym brzmieniem tego przepisu ograniczona jest do samej treści przedkładanego regulaminu, tym bardziej że - jak to wynika z normatywnego wzoru regulaminu - jego treść obejmuje jedynie warunki korzystania ze strzelnicy, sposobu obchodzenia się z bronią oraz sposobu zachowania się osób przebywających na strzelnicy. Nie regulują więc całości problematyki związanej z legalnym funkcjonowaniem strzelnicy, w tym zwłaszcza kwestii jej lokalizacji i konstrukcji. Na taki - ograniczony przedmiotowo - charakter wydanego na podstawie art. 47 u.o.b.a. rozstrzygnięcia wskazują także jego skutki. Decyzja zatwierdzająca regulamin konkretyzuje jedynie uprawnienia i obowiązki osoby prowadzącej strzelnicę, a pośrednio także osób korzystających ze strzelnicy, w zakresie objętym treścią regulaminu ${ }^{11}$.

10 Zob. J. Majo, Zatwierdzenie regulaminu strzelnicy - według sadu, Strzał.pl 6/2019, s. 81.

11

Zob. A. Turczyn, Organ (wójt, burmistrz, prezydent miasta) zatwierdzający regulamin strzelnicy nie jest uprawniony do badania innych kwestii niż sama treść regulaminu, https://trybun.org.pl/2019/05/22/organ-wojt-burmistrz-prezydent-miasta-zatwier- 
Mając powyższe na uwadze, z treści art. 47 u.o.b.a. nie sposób wywieść wniosku o możliwości wydania decyzji o dopuszczeniu strzelnicy do użytku przez wymienione organy administracji. Trafna w tym kontekście jest uwaga A. Lipińskiego, że rozwiązania wyznaczające właściwość organu administracji muszą być interpretowane w sposób ścisły. W szczególności zaś właściwości tej nie można domniemywać. Milczenie ustawy, która nie zawiera rozwiązania wskazującego na właściwość danego organu w określonej kategorii, spraw musi być traktowane jako argument przemawiający przeciwko jego kompetencji w tym zakresie. W istocie bowiem właściwość organu administracji to nic innego jak jego zdolność prawna (a niekiedy obowiązek) do działania w danej kategorii spraw. Naruszenie tej właściwości skutkuje nieważnością podejmowanych rozstrzygnięć ${ }^{12}$. $\mathrm{Na}$ identycznym stanowisku stoi W. Chróścielewski, konstatując, iż na gruncie przepisów Kodeksu postępowania administracyjnego, a zwłaszcza jego art. 156 $\S 1$ pkt 1 , należy mówić nie o jakiejś abstrakcyjnej właściwości organu administracji do rozpoznawania $\mathrm{z}$ góry założonej kategorii spraw, ale o właściwości organu do rozpatrzenia i załatwienia indywidualnej (podwójnie konkretnej) sprawy będącej przedmiotem wszczynanego postępowania administracyjnego $^{13}$. Tym samym jakiekolwiek działania organu wykraczające poza określone prawem kompetencje skutkują nieważnością decyzji administracyjnej na podstawie art. $156 \$ 1$ pkt 1 Kodeksu postępowania administracyjnego. Podkreśla to stanowczo również J. Goleniowska-Gałgan. Zdaniem tej autorki prawodawca w takiej sytuacji nie mógł inaczej postąpić, jak nałożyć sankcję nieważności za naruszenie przepisów o właściwości. Podyktowane zostało to faktem, że w tymże przypadku brakuje podmiotu legitymującego do zawiązania stosunku prawnego. Legitymacja jest zaś niezbędnym warunkiem prawidłowości rozstrzygania sprawy. Tylko organ administracji, działając w ramach przyznanych kompetencji, może z trwałym skutkiem regulować prawne stosunki ${ }^{14}$. Zatem jakiekolwiek próby wydania decyzji administracyjnej dopuszczające (lub nie) strzelnice do użytkowania (a nie oscylujące jedynie w granicach zatwierdzenia regulaminu strzelnicy) ipso iure będą nieważne. Ta kwestia będzie miała także swoje reperkusje w odniesieniu do obowiązku wywieszania decyzji o dopuszczeniu strzelnicy do użytkowania, o czym będzie jeszcze mowa w dalszej części naszych rozważań.

dzajacy-regulamin-strzelnicy-nie-jest-uprawniony-do-badania-innych-kwestii-niz-sama-tresc-regulaminu/ [dostęp 7 stycznia 2020 r.]. Także O. Rudak, Czy zatwierdzenie regulaminu strzelnicy jest pierwszym - czy ostatnim - etapem organizacji obiektu?, Lege Artis, 27 listopada 2019 r., https://czasopismo.legeartis.org/2019/11/zatwierdzenie-regulaminu-strzelnicy.html [dostęp 7 stycznia 2020 r.].

12 Zob. A. Lipiński, Z problematyki właściwości rzeczowej organów administracji geologicznej, LEX nr 151169595.

13 Zob. W. Chróścielewski, Z problematyki właściwości organów w postępowaniu administracyjnym, LEX nr 151145294.

14 Zob. J. Goleniowska-Gałgan, Właściwość organów administracji, LEX nr 151109885. 
Sformułowane w taki sposób przez prawodawcę przepisy prawne oraz stanowisko doktryny nie zabezpieczają jednak ipso iure przed przekroczeniem granic kompetencyjnych w tej materii przez administrację samorządową, jak również są przyczyną rozbieżnych stanowisk sądów administracyjnych oscylujących wokół dwóch wariantów: równoległego, nazywanego również rozproszonym, oraz liniowego, określanego często szeregowym.

Dobrym przykładem interpretacji równoległej (rozproszonej) może być wyrok Wojewódzkiego Sądu Administracyjnego w Gdańsku z 14 marca 2019 r. ${ }^{15}$ w sprawie dotyczącej strzelnicy Skorpion w miejscowości Korne k/Kościerzyny ${ }^{16}$, w którym WSA podzielił stanowisko wcześniej wyrażone przez Samorządowe Kolegium Odwoławcze (SKO) w przedmiocie odmowy stwierdzenia nieważności decyzji wójta dotyczącej zatwierdzenia regulaminu strzelnicy. Sąd, powołując się na uzasadnienie SKO podkreślił, że „organ prowadzący postępowanie w oparciu o art. 47 ustawy o broni i amunicji nie jest uprawniony do badania innych kwestii niż sama treść regulaminu. Zgodnie z tym stanowiskiem kwestia, czy i jakiego rodzaju obiektem budowlanym jest strzelnica nie należy do zakresu badania w postępowaniu dotyczącym zatwierdzenia «regulaminu strzelnicy». Przedmiotem oceny dokonywanej w powyższym zakresie nie jest także spełnienie wymogów ochrony środowiska określonych w rozporządzeniu Ministra Środowiska z dnia 4 kwietnia 2000 r. w sprawie wymagań w zakresie ochrony środowiska dotyczących budowy i użytkowania strzelnic. Wymogi te badane są przez organy właściwe w sprawie ochrony środowiska. [...] Rażące naruszenie prawa zachodzi w przypadku naruszenia przepisu, którego treść bez żadnych wątpliwości interpretacyjnych może być ustalona w bezpośrednim rozumieniu. Regulacja zawarta w art. 47 u.b.a. [ustawie o broni i amunicji - dopisek B.N.] nie uzależnia wprost zatwierdzania regulaminu strzelnicy od badania wszelkich warunków funkcjonowania strzelnicy na danym terenie i w ujęciu szerszym niż tylko ograniczonym do samego tekstu regulaminu. Skoro na konieczność taką wskazuje orzecznictwo sądów administracyjnych w procesie wykładni prawa, Sąd podziela pogląd Kolegium, że Wójtowi Gminy nie można postawić skutecznego zarzutu wydania kwestionowanej decyzji z rażącym naruszeniem prawa" ${ }^{17}$.

15 Wyrok WSA w Gdańsku z 14 marca 2019 r., sygn. akt III SA/Gd 915/18, LEX nr 2650936. Zob. także A. Turczyn, Przełomowy wyrok sądu administracyjnego, który rozprawia się ze wszystkimi naruszeniami prawa w sprawach o zatwierdzanie regulaminów strzelnic, https://trybun.org.pl/2018/01/03/przelomowy-wyrok-sadu-administracyjnego/ [dostęp 7 stycznia 2020 r.].

16 Szerzej na temat tej sprawy w: A. Turczyn, Strzelnica padła ofiarq walki politycznej, https://trybun.org.pl/2018/07/30/strzelnica-padla-ofiara-walki-politycznej/ [dostęp 7 stycznia $2020 \mathrm{r}$.].

17 Wyrok WSA w Gdańsku z 14 marca 2019 r., sygn. akt III SA/Gd 915/18, LEX nr 2650936. 
W podobnym tonie wypowiedział się również Wojewódzki Sąd Administracyjny w Lublinie w wyroku z 15 listopada 2017 r. ${ }^{18}$. Na marginesie należy zaznaczyć, że powołany wyżej wyrok WSA w Gdańsku powołuje się na uzasadnienie prawne WSA w Lublinie. Sąd ten wskazał jednoznacznie, że „przedmiotem badania w sprawie zatwierdzenia regulaminu strzelnicy jest przedstawiony przez właściciela lub zarządcę strzelnicy regulamin, opracowany na podstawie wzorcowego regulaminu strzelnic, stanowiącego załącznik do rozporządzenia. Decyzja o zatwierdzeniu regulaminu powinna zatem zostać podjęta po analizie postanowień regulaminu i ocenie ich zgodności z regulaminem wzorcowym oraz wymogami zapewnienia bezpieczeństwa osób korzystających ze strzelnicy i osób przebywających na strzelnicy. Ustawa nie uzależnia zatwierdzenia regulaminu strzelnicy od spełnienia dodatkowych warunków, w szczególności od przedstawienia pozwolenia na budowę czy decyzji o dopuszczeniu strzelnicy do użytkowania, jak twierdzą organy obu instancji w sprawie niniejszej. Regulamin dotyczy strzelnicy jako obiektu przeznaczonego do prowadzenia strzelań szkoleniowych, sportowych i rekreacyjnych oraz treningów strzeleckich ( $\$ 2$ pkt 1 rozporządzenia w sprawie wzorcowego regulaminu). Kwestia, czy i jakiego rodzaju obiektem budowlanym jest strzelnica nie należy do zakresu badania w postępowaniu dotyczącym zatwierdzenia regulaminu strzelnicy. Ocena, czy strzelnica jest obiektem budowlanym oraz czy spełnia wymogi dotyczące budowy i utrzymania obiektów budowlanych, określone w ustawie z dnia 7 lipca 1994 r. - Prawo budowlane (Dz.U. z 2017 r. poz. 1332 z późn. zm.), należy do organów administracji architektoniczno-budowlanej i organów nadzoru budowlanego. [...] Nie jest także przedmiotem oceny w sprawie zatwierdzenia regulaminu strzelnicy spełnienie wymogów ochrony środowiska, określonych w rozporządzeniu Ministra Środowiska z dnia 4 kwietnia 2000 r. w sprawie wymagań w zakresie ochrony środowiska dotyczących budowy i użytkowania strzelnic (Dz.U. Nr 27, poz. 341). Wymogi te badane są przez organy właściwe w sprawie ochrony środowiska"19.

Zgoła odmienne stanowisko sądów administracyjnych można spotkać w tzw. ujęciu liniowym lub szeregowym. Zakłada ono, że podjęcie określonej działalności możliwe jest dopiero po spełnieniu określonych prawem warunków potwierdzanych kolejno uzyskiwanymi rozstrzygnięciami organów administracji publicznej, z których wcześniejsze warunkują wydanie kolejnych. W tym wypad-

18 Wyrok WSA w Lublinie z 15 listopada 2017 r., sygn. akt III SA/Lu 216/17, LEX nr 2407704.

19 Wyrok WSA w Lublinie z 15 listopada 2017 r., sygn. akt III SA/Lu 216/17, LEX nr 2407704. Podobne stanowisko wyraził WSA w Lublinie w wyroku z 17 października 2019 r., sygn. akt III SAB/Lu 28/19, CBOSA: „W ocenie Sądu, z powołanych powyżej przepisów nie można wyprowadzić wniosku, że decyzja o dopuszczeniu strzelnicy do użytkowania jest warunkiem formalnym wniosku o zatwierdzenie regulaminu strzelnicy, bez którego nie można nadać wnioskowi dalszego biegu”. Zob. także wyrok WSA w Szczecinie z 13 września 2018 r., sygn. akt II SA/Sz 216/18, CBOSA. 
ku podejmując rozstrzygnięcie w zakresie swoich kompetencji, kolejne organy zobowiązane są ustalić, czy i jak zakończyły się wcześniejsze postępowania oraz czy inwestor legitymuje się wcześniej uzyskanymi pozytywnymi orzeczeniami. W tę linię orzeczniczą wpisuje się wyrok Wojewódzkiego Sądu Administracyjnego w Poznaniu z 25 października 2005 r., poddający krytyce działanie Burmistrza Gminy i Miasta W., który w decyzji z dnia [...] lipca 2003 r., nr [...], zatwierdził regulamin pewnej strzelnicy myśliwsko-sportowej, wskazując jako jej podstawę prawną art. 47 ustawy z 21 maja 1999 r. o broni i amunicji (Dz.U. nr 53, poz. 549, ze zm.). WSA w Poznaniu nie zgodził się z uzasadnieniem powyższej decyzji (idącej po linii interpretacji rozproszonej) i poddał je surowej krytyce, zauważając, że „organ pierwszej instancji orzekający w niniejszej sprawie w ogóle nie ustalał, czy właściciel strzelnicy uzyskał pozwolenie na jej budowę (co wydaje się wątpliwe wobec treści umowy dzierżawy terenu z dnia [...].10.2001 r. oraz przeznaczenia terenu w planie miejscowym zagospodarowania przestrzennego na lasy) oraz czy uzyskał nadto pozwolenie na jej użytkowanie od organu nadzoru budowlanego. Organ zatem, zatwierdzając regulamin strzelnicy należącej do skarżącego, w ogóle nie zainteresował się czy taki obiekt powstał zgodnie z przepisami prawa" ${ }^{20}$.

Podobne stanowisko zajął Wojewódzki Sąd Administracyjny w Bydgoszczy w wyroku z 21 listopada 2016 r., stwierdzając, że „zasadne jest, aby organ, któremu przedłożono wniosek o zatwierdzenie regulaminu strzelnicy, najpierw poczynił ustalenia, czy obiekt, którego regulamin ma być zatwierdzony, rzeczywiście jest strzelnicą, tj. obiektem budowlanym wzniesionym zgodnie z przepisami prawa, przeznaczony do użytkowania jako strzelnica. [...] Strzelnica jest tego rodzaju obiektem, który należy kwalifikować jako obiekt budowlany, w konsekwencji daje to podstawę nie do oceny całego procesu budowlanego (w taki sposób jak czynią to organy architektoniczno-budowlane czy nadzoru budowlanego), ale jedynie do żądania, aby wnioskujący o zatwierdzenie regulaminu strzelnicy (tj. szczególnego rodzaju zasad użytkowania obiektu, nie ujętych w Prawie budowlanym) wykazał się posiadaniem stosownych dokumentów (np. pozwoleniem na budowę, dowodem zgłoszenia, pozwoleniem na użytkowanie), świadczących o tym, że ten konkretny obiekt jest w sposób legalny przeznaczony do użytkowania jako strzelnica. Trudno byłoby bowiem zaakceptować np. sytuację, że organizator strzelnicy może uzyskać zatwierdzenie regulaminu strzelnicy zorganizowanej w obiekcie będącym samowolą budowlaną, tj. w obiekcie, który zgodnie z prawem w ogóle nie może być użytkowany. Prawo nie może wynikać z bezprawia" ${ }^{21}$.

20 Wyrok WSA w Poznaniu z 25 października 2005 r., sygn. akt II SA/Po 2807/03, Legalis $\mathrm{nr} 2207003$.

21 Wyrok WSA w Bydgoszczy z 24 stycznia 2018 r., sygn. akt II OSK 1462/17, LEX nr 2446376. 
Wyrok ten nie zakończył jednak sprawy, która w drodze skargi kasacyjnej trafiła do Naczelnego Sądu Administracyjnego. Ten, analizując sprawę, zajął stanowisko jak Wojewódzki Sąd Administracyjny w Bydgoszczy, konkludując, że „Sąd I instancji dokonał prawidłowej wykładni art. 46 ust. 1 i 2 w zw. z art. 47 ustawy o broni i amunicji, zgodnie z którą wójt gminy posiada kompetencję do weryfikowania (badania), czy strzelnica zbudowana jest $\mathrm{z}$ zachowaniem wymogów prawa budowlanego oraz czy jest dopuszczona do użytku w rozumieniu przepisów, m.in. przez żądanie przedłożenia przez wnioskodawcę pozwolenia na użytkowanie obiektu. [...] W tym zakresie w trakcie postępowania dotyczącego zatwierdzenia regulaminu strzelnicy wójt może dokonać ustaleń odnośnie faktu, czy wnioskodawca posiada uprawnienie do zlokalizowania strzelnicy w danym miejscu, czy strzelnica powstała zgodnie z prawem na podstawie odpowiednich zgód m.in. organów architektoniczno-budowlanych [...]. Są to zatem okoliczności, które powinny być przedmiotem postępowania wyjaśniającego prowadzonego na podstawie art. 7 i art. $77 \$ 1$ k.p.a., które Wójt powinien ustalić przed zatwierdzeniem regulaminu strzelnicy"22.

Jeszcze bardziej zaskakująca jest dalsza część prawna uzasadnienia wyroku. Naczelny Sąd Administracyjny uznał, że „strona skarżąca kasacyjnie nie wykazała, aby istniał jakikolwiek przepis obowiązującego prawa, który w odniesieniu do strzelnic wyłączałby zastosowanie zasad wynikających w ww. ustaw. Takiego wyraźnego wyłączenia nie zawiera zaś ustawa o broni i amunicji. To, że na podstawie art. 5 ustawy z dnia 27 marca 2003 r. o zmianie ustawy - Prawo budowlane oraz o zmianie niektórych ustaw «zdjęto» $\mathrm{z}$ wójta (burmistrza, prezydenta miasta) kompetencję do dopuszczenia strzelnicy do użytkowania nie oznacza, że aktualnie tego rodzaju zagadnienie nie jest w sposób prawny uregulowane. Mają bowiem w tym zakresie zastosowanie ogólne reguły wynikające z Prawa budowlanego. [...] Stąd zatem wynikało uprawnienie Wójta do ustalenia w okolicznościach tej sprawy, czy wnioskodawca może użytkować strzelnicę zgodnie z prawem"23.

Wreszcie zarówno Wojewódzki Sąd Administracyjny w Gliwicach, jak i Wojewódzki Sąd Administracyjny w Białymstoku explicite odcięły się od orzeczeń prezentujących linię równoległą (rozproszoną). Pierwszy z wymienionych wyroków, z 22 listopada 2018 r., powołując się na przytoczony wyżej wyrok Naczelnego Sądu Administracyjnego z 24 stycznia 2018 r., wskazał, że „chybione są zarzuty skargi dotyczące przekroczenia kompetencji organów orzekających w tej sprawie. Nie oceniały one bowiem zgodności lokalizacji budowy, czy użytkowania

22 Wyrok NSA z 24 stycznia 2018 r., sygn. akt II OSK 1462/17, LEX nr 2446376.

23 Wyrok NSA z 24s tycznia 2018 r., sygn. akt II OSK 1462/17, LEX nr 2446376. W podobnym duchu również: wyrok WSA w Gliwicach z 22 listopada 2018 r., sygn. akt IV SA/GI 797/18, LEX nr 2600526, oraz wyrok WSA w Rzeszowie z 27 marca 2018 r., sygn. akt II SA/Rz 66/18, LEX nr 2485969. 
strzelnicy z odrębnymi przepisami lecz stwierdziły, że skarżący nie przedstawił dokumentów potwierdzających taką zgodność. Nie do przyjęcia jest pogląd skarżącego, że stosowanie art. 47 u.o.b.a., polegać ma wyłącznie na sprawdzeniu, czy zapisy objętego wnioskiem regulaminu są zgodne $z$ regulaminem wzorcowym. Zatwierdzeniu podlega bowiem regulamin strzelnicy, a więc konkretnego obiektu. [...] zatwierdzenie regulaminu nie może się odnosić abstrakcyjnie do mającej dopiero powstać strzelnicy. W przeciwnym razie wnioskować można byłoby zatwierdzenie regulaminu strzelnicy projektowanej w dowolnym miejscu, nawet w sposób oczywisty nie nadającym się na jej urządzenie. [...] Dla zatwierdzenia regulaminu niezbędne jest zatem uprzednie potwierdzenie legalności lokalizacji i budowy strzelnicy oraz możliwości przystąpienia do jej użytkowania"24. W drugim z wymienionych wyroków, z 17 października 2019 r., Sąd zauważył, że „prezentując powyższe stanowisko skład orzekający nie podziela tym samym poglądu prezentowanego w niektórych orzeczeniach sądów administracyjnych, w których wskazuje się, że zatwierdzenie regulaminu strzelnicy nie jest uzależnione od istnienia formalnoprawnych zgód na realizację strzelnicy (np. III SA/ Lu 216/17 czy III SA/Gd 915/18, CBOSA)"25.

\section{Obowiązek umieszczenia w widocznym miejscu decyzji o dopuszczeniu strzelnicy do użytkowania}

Spore kontrowersje wzbudza również znajdujący się w rozporządzeniu MSWiA o wzorcowym regulaminie bezpiecznego funkcjonowania strzelnic obowiązek umieszczenia w widocznym miejscu decyzji o dopuszczeniu strzelnicy do użytkowania $^{26}$. Przepis ten ${ }^{27}$ powinien zostać usunięty z rozporządzenia z $2000 \mathrm{r}$.,

24 Wyrok WSA w Gliwicach z 22 listopada 2018 r., sygn. akt IV SA/GI 797/18, LEX nr 2600526. Analogiczna linia orzecznicza prezentowana jest m.in. w: wyrok WSA w Bydgoszczy z 21 listopada 2016 r., sygn. akt II SA/Bd 416/16, CBOSA; wyrok WSA w Kielcach z 13 lutego 2020 r., sygn. akt II SA/Ke 1117/19, CBOSA („W ocenie Sądu nie może budzić wątpliwości to, że zatwierdzenie regulaminu strzelnicy jest ostatnim etapem na drodze do rozpoczęcia użytkowania takiego obiektu oraz, że postępowanie mające na celu zatwierdzenie regulaminu strzelnicy nie jest jedynym postępowaniem administracyjnym, poprzedzającym możliwość rozpoczęcia jej faktycznego użytkowania."); wyrok WSA w Szczecinie z 7 marca 2019 r., sygn. akt II SA/Sz 1108/18, CBOSA; wyrok WSA w Bydgoszczy z 19 grudnia 2018 r., sygn. akt II SA/Bd 971/17, CBOSA; wyrok WSA w Rzeszowie z 27 marca 2018 r., sygn. akt II SA/Rz 66/18, LEX nr 2485969.

25 Wyrok WSA w Białymstoku z 17 października 2019 r., sygn. akt II SA/Bk 484/19, LEX nr 2738260.

Rozporządzenie MSWiA w sprawie wzorcowego regulaminu strzelnic, dokument cyt. 
ponieważ nie ma umocowania w ustawie o broni i amunicji. W czasie wprowadzania w życie rozporządzenia w ustawie o broni i amunicji funkcjonowało pojęcie „dopuszczenie strzelnicy do użytkowania”. Przepis rozporządzenia odnosił się właśnie do tego punktu ustawy o broni i amunicji. Jednak po nowelizacji ustawy o broni i amunicji w 2003 r. - o czym wspomniano już wyżej - z art. 47 u.o.b.a. został wykreślony fragment dotyczący dopuszczenia strzelnicy do użytkowania, a pozostawiono jedynie wymóg zatwierdzenia regulaminu strzelnicy przez wójta (burmistrza, prezydenta miasta). Zatem zmiana merytoryczna art. 47 u.o.b.a. spowodowała określone skutki, mianowicie zawężono kompetencje organu administracji. W związku z powyższym w trakcie prowadzenia postępowania w sprawie zatwierdzenia regulaminu strzelnicy nie jest zasadne żądanie przez wójta (burmistrza, prezydenta miasta) dostarczenia decyzji o dopuszczenia obiektu do użytkowania ${ }^{28}$. Pojawia się pytanie: jaki organ administracji miałby ją wydać, skoro ustawodawca takowego nie wskazuje? Co więcej, konieczne byłoby uregulowanie tej materii przynajmniej na poziomie ustawowym, gdyż normy kompetencyjne dotyczące organów administracji publicznej w Rzeczpospolitej tego wymagają. Tym samym również nie ma zastosowania przepis mówiący o umieszczeniu takiej decyzji na strzelnicy, gdyż nie ma on w chwili obecnej umocowania w obowiązującej ustawie o broni i amunicji.

Ponadto, jak zaznacza we wspomnianej już na wstępie interpelacji do MSWiA poseł Jarosław Stawiarski, zmiana ta, za sprawą zaniechania legislacyjnego, nie znalazła odzwierciedlenia w załączniku do rozporządzenia MSWiA z 15 marca 2000 r. i wymóg umieszczenia na strzelnicy w widocznym miejscu decyzji o dopuszczeniu strzelnicy do użytkowania nadal figuruje. Z uwagi na fakt, że przepis rozporządzenia jest sprzeczny $z$ aktem prawnym wyższego rzędu, jakim jest unormowanie ustawowe, należy wskazać, iż decyzja o dopuszczeniu strzelnicy do użytkowania nie musi (i nie może) być wywieszona na strzelnicy, ponieważ decyzji takich nie wydaje się ${ }^{29}$. W niespełna miesiąc później sekretarz stanu MSWiA Jarosław Zieliński (z up. Ministra Spraw Wewnętrznych i Administracji) poinformował, że „obecnie w MSWiA nie jest planowane podjęcie prac legislacyjnych mających na celu zmianę rozporządzenia w sprawie wzorcowego regulaminu strzelnic, niemniej kwestia dotycząca wymogu umieszczania na strzelnicy w widocznym miejscu decyzji o dopuszczeniu strzelnicy do użytkowania wymaga rozważenia"30. Warto na marginesie zaznaczyć, że od tamtej pory, czyli od ponad trzech lat, w sprawie tej nie podjęto żadnych zmian legislacyjnych.

28 Zob. H. Kowalik, Aspekty formalne projektu „Strzelnica w powiecie”, op. cit., s. 29.

29 Zob. J. Stawiarski, Interpelacja nr 10011 do ministra spraw wewnętrznych i administracji, op. cit.

30 J. Zieliński, sekretarz stanu w Ministerstwie Spraw Wewnętrznych i Administracji, Odpowiedź na interpelacje $\mathrm{nr} 10011 \mathrm{w}$ sprawie wzorcowego regulaminu strzelnic, 14 marca 2017 r., http://www.sejm.gov.pl/Sejm8.nsf/InterpelacjaTresc.xsp?key=2AE714C2 [dostęp 7 stycznia 2020 r.]. 
Podobne stanowisko zajął również Wojewódzki Sąd Administracyjny w Lublinie w wyroku z 15 listopada 2017 r.: „zawarte we wzorcowym regulaminie postanowienie dotyczące umieszczenia w widocznym miejscu decyzji o dopuszczeniu strzelnicy do użytkowania straciło na aktualności, ponieważ przepis art. 47 ustawy, który przewidywał wydanie przez wójta gminy decyzji o dopuszczeniu strzelnicy do użytkowania zmieniony został z dniem 11 lipca 2003 r. przez art. 5 ustawy z 27 marca 2003 r. o zmianie ustawy - Prawo budowlane oraz o zmianie niektórych ustaw (Dz.U. nr 80, poz. 718). Skoro ustawa nie przewiduje już wydawania przez wójta decyzji o dopuszczeniu strzelnicy do użytkowania, zbędne jest zamieszczanie tego postanowienia w regulaminie" ${ }^{31}$.

Niestety, analogicznie jak w odniesieniu do procedury zatwierdzenia regulaminu strzelnicy, tak i w tym przypadku mamy do czynienia $\mathrm{z}$ diametralnie rozbieżnym stanowiskiem w orzecznictwie i doktrynie. Naczelny Sąd Administracyjny w wyroku z 24 stycznia 2018 r. skonstatował, że „uzyskanie w tym zakresie stosownej zgody właściwego organu, z uwagi także na cele Prawa budowlanego, stanowi potwierdzenie użytkowania obiektu, w tym strzelnicy, zgodnie z wymogami bezpieczeństwa i ochrony środowiska. Ponadto Sąd I instancji prawidłowo ocenił, że prawidłowe funkcjonowanie strzelnicy uzależnione jest od [...] zatwierdzenia regulaminu strzelnicy, zgodnie z którym prowadzący strzelnicę powinien na strzelnicy w widocznym miejscu umieścić m.in. decyzję o dopuszczeniu strzelnicy do użytkowania. Brak takiej decyzji stanowi zatem przeszkodę do stwierdzenia czy przedstawiony do zatwierdzenia regulamin strzelnicy będzie rzeczywiście spełniał wymogi związane $\mathrm{z}$ odpowiednim funkcjonowaniem strzelnicy"32. Odmienne stanowisko jeszcze dobitniej wybrzmiało w wyroku Wojewódzkiego Sądu Administracyjnego w Białymstoku z 17 października 2019 r., gdzie podkreślono, że rzeczywiście „Z dniem 11 lipca 2003 r. doszło do zmiany treści art. 47 u.b.a. Obecnie organ zatwierdzający regulamin strzelnicy nie dopuszcza strzelnicy do użytkowania, ale wyłącznie zatwierdza regulamin. Nie oznacza to jednak, że wymóg formalnoprawnego dopuszczenia do użytkowania przestał być wymogiem prawnym. W ust. 3 pkt 2 załącznika do rozporządzenia w sprawie wzorcowego regulaminu strzelnic sformułowano wprost obowiązek uzyskania decyzji o dopuszczeniu strzelnicy do użytkowania. Ustawodawca zatem także i w tym przepisie potwierdził, że realizacja strzelnicy wymaga formalnoprawnych zgód, w tym zezwalających na użytkowanie strzelnicy"33.

W linię przytoczonego odmiennego orzecznictwa wpisuje się również S. Maj, który w komentarzu do ustawy o broni i amunicji stwierdza, że od 31 marca

31 Wyrok WSA w Lublinie z 15 listopada 2017 r., sygn. akt III SA/Lu 216/17, LEX nr 2407704.

32 Wyrok NSA z 24 stycznia 2018 r., sygn. akt II OSK 1462/17, LEX nr 2446376.

33 Wyrok WSA w Białymstoku z 17 października 2019 r., sygn. akt II SA/Bk 484/19, LEX nr 2738260. 
2002 r., kiedy to w pkt 3 ppkt 2 - Wzorcowego regulaminu bezpiecznego funkcjonowania strzelnic, treść „aktualny atest strzelnicy” zmieniono na „decyzję o dopuszczeniu strzelnicy do użytkowania”, nie wymaga się od strzelnicy atestu, a jedynie decyzji o dopuszczeniu jej do użytkowania w rozumieniu prawa budowlanego. Taką decyzję umieszcza się na widocznym miejscu strzelnicy, podobnie jak regulamin, plan strzelnicy, wykaz sygnałów alarmowych, informację o możliwości i sposobie połączenia się z najbliższym punktem pomocy medycznej. Tyle mówią przepisy powszechnie obowiązującego prawa, które określają niezbędne minimum ${ }^{34}$.

\section{Podsumowanie}

Nie ulega wątpliwości, że inicjatywa władz państwowych związana z budową, remontami i utrzymaniem strzelnic oraz rozwijaniem sportu strzeleckiego, w szczególności wśród dzieci i młodzieży, oraz organizacji proobronnych jest wartościowym i perspektywicznym współdziałaniem administracji państwowej i samorządowej, a korzyści z tego płynące są wielopłaszczyznowe i nie do przecenienia. Ponadto szczególnie cenne wydaje się zaktywizowanie potencjału zwykłych obywateli, dla których program państwa stał się impulsem do działań oddolnych środowisk lokalnych. Niestety w wielu sytuacjach działaniom tym na przeszkodzie staje nieprecyzyjny stan prawny, a także rozbieżności w jego interpretacji oraz w orzecznictwie sądów administracyjnych. Analizowane wcześniej regulacje prawne dotyczące zasad funkcjonowania i lokalizowania strzelnic zostały opracowane kilkanaście lat temu. Jak zauważył H. Kowalik, niektóre z nich stoją w chwili obecnej w sprzeczności ze sobą lub ich umocowanie w ustawie o broni i amunicji wygasło. Wydaje się zatem zasadne rozważenie możliwości wprowadzenia pewnych zmian oraz dostosowanie ich do obecnych potrzeb. $\mathrm{Ma}$ to istotne znaczenie $\mathrm{w}$ kwestii wprowadzenia precyzyjnej i kompatybilnej procedury zatwierdzenia regulaminu strzelnicy przez danego wójta, burmistrza czy prezydenta miasta, aby wyeliminować uznaniowość w tym zakresie ${ }^{35}$. W tym miejscu należy również podkreślić, że w aktualnym stanie prawnym wójt (burmistrz, prezydent miasta) nie ma kompetencji do wydawania decyzji o dopuszczeniu strzelnicy do użytkowania, co oznacza, że taka decyzja jest nieważna. Zatem obowiązek uregulowany w rozdziale 1 pkt 3 ppkt 2 rozporządzenia w sprawie wzorcowego regulaminu strzelnic jest w istocie kuriozalny. Nie ulega również wątpliwości, że także formalny aspekt dopuszczenia strzelnicy do użytkowania wymaga rewizji. W formie integralnej nie jest on jednak przedmiotem niniejszej analizy, którym pozostaje wyłącznie jeden z jego aspektów - czynność

34 S. Maj, Ustawa o broni i amunicji, op. cit., art. 46.

35 Zob. H. Kowalik, Aspekty formalne projektu „Strzelnica w powiecie”, op. cit., s. 30. 
administracyjna zatwierdzenia regulaminu strzelnicy. Niezależnie od formy rozwiązań prawnych, jakie zostaną podjęte w przyszłości, słuszne wydaje się oparcie ich na stanowisku teorii równoległej (rozproszonej) z kilku względów.

Po pierwsze, prawodawca w kompetencji organu administracji samorządowej pozostawił wyłącznie zatwierdzenie regulaminu strzelnicy, odstępując od konieczności wcześniejszego dodatkowego dopuszczenia do jej użytkowania. Oznacza to, że organ nie jest uprawniony do badania innych kwestii niż tylko treść regulaminu. Jego rolą jest wyłącznie ocena regulaminu strzelnicy z punktu widzenia zgodności z wzorcem normatywnym określonym w rozporządzeniu MSWiA z 15 marca 2000 r. w sprawie wzorcowego regulaminu strzelnic, a więc pod kątem przyjęcia odpowiednich rozwiązań dotyczących sposobu korzystania ze strzelnicy i obchodzenia się na niej z bronią. Poza kompetencjami organu pozostaje zatem weryfikowanie pozostałych dokumentów związanych ze strzelnicą, wymaganych przez inne niż ustawa o broni i amunicji przepisy, np. prawa budowlanego, zagospodarowania przestrzennego, ochrony środowiska. Te sprawy jako wynikające z przepisów odrębnych - podlegają rozpatrzeniu w trybie i na zasadach określonych w tychże przepisach, a nie w postępowaniu prowadzonym na podstawie ustawy o broni i amunicji.

Po drugie, z przepisów obowiązującego prawa nie wynika, aby decyzja w sprawie zatwierdzenia regulaminu strzelnicy była aktem finalnym (jak twierdzą niektóre sądy administracyjne), kończącym i niejako podsumowującym z punktu widzenia zgodności z prawem cały proces organizowania strzelnicy, a w konsekwencji stanowiącym wyłączną podstawę przystąpienia do jej legalnego użytkowania, co zbliżałoby tę decyzję w swej konstrukcji do swoistego zezwolenia na prowadzenie strzelnicy.

Po trzecie, znajdujący się w rozporządzeniu MSWiA o wzorcowym regulaminie bezpiecznego funkcjonowania strzelnic zapis o umieszczeniu w widocznym miejscu decyzji o dopuszczeniu strzelnicy do użytkowania powinien zostać usunięty, ponieważ nie ma umocowania w ustawie o broni i amunicji. Wprawdzie w czasie wydawania rozporządzenia w ustawie o broni i amunicji funkcjonował zapis o „dopuszczeniu strzelnicy do użytkowania”, jednak po nowelizacji ustawy o broni i amunicji w 2003 r. z art. 47 u.o.b.a. został on wykreślony, a pozostawiono jedynie wymóg zatwierdzenia regulaminu strzelnicy przez wójta (burmistrza, prezydenta miasta).

W związku z dyrektywą Parlamentu Europejskiego i Rady (UE) 2017/853 z 17 maja 2017 r. zmieniającą dyrektywę Rady 91/477/EWG w sprawie kontroli nabywania i posiadania broni ${ }^{36}$ Polska została zobowiązana do przeprowadzenia nowelizacji ustawy o amunicji i broni. Ma ona na celu przede wszystkim dostoso-

36 Dyrektywa Parlamentu Europejskiego i Rady (UE) 2017/853 zmieniająca dyrektywę Rady 91/477/EWG w sprawie kontroli nabywania i posiadania broni, 17 maja 2017 r., Dz.Urz. UE L 137/22-39 z 2017 r. 
wanie przepisów prawa dostępu do broni i jej posiadania przez obywateli Rzeczpospolitej Polskiej do wymogów, które zostały zawarte w dyrektywie. Trudno zatem wyobrazić sobie lepszy moment do przeprowadzenia de lege ferenda tych słusznych, koniecznych i pilnych zmian jak ten, którego ramy czasowe zakreśla wspomniana dyrektywa.

\section{Bibliografia}

\section{Literatura}

Barszczewska B., Regulamin strzelnicy musi być zatwierdzony przez wójta, Prawo.pl 18.10.2016, https://www.prawo.pl/samorzad/regulamin-strzelnicy-musi-byc-zatwierdzony-przez-wojta,106908.html

Chróścielewski W., Z problematyki właściwości organów w postępowaniu administracyjnym, LEX nr 151145294.

Goleniowska-Gałgan J., Właściwość organów administracji, LEX nr 151109885.

Kowalik H., Aspekty formalne projektu „Strzelnica w powiecie” [w:] Obrona Narodowa, Sokót - Strzelnica w powiecie. Publikacja po konferencji 9-10 grudnia 2017 w Warszawie, Warszawa 2017.

Lewandowski J., Sokót - strzelnica w powiecie, Strzał.pl 1/2018.

Lipiński A., Z problematyki właściwości rzeczowej organów administracji geologicznej, LEX nr 151169595.

Maj S., Ustawa o broni i amunicji. Komentarz, art. 47, LEX nr 16836326.

Majo J., Zatwierdzenie regulaminu strzelnicy - według sądu, Strzał.pl 6/2019.

Rudak O., Czy zatwierdzenie regulaminu strzelnicy jest pierwszym - czy ostatnim - etapem organizacji obiektu?, Lege Artis, 27 listopada 2019, https://czasopismo.legeartis. org/2019/11/zatwierdzenie-regulaminu-strzelnicy.html.

Stawiarski J., Interpelacja nr 10011 do ministra spraw wewnętrznych $i$ administracji w sprawie wzorcowego regulaminu strzelnic, 9.02.2017 r., http://www.sejm.gov.pl/Sejm8.nsf/ InterpelacjaTresc.xsp?key=13829D7B.

Turczyn A., MON ogłasza konkurs pn. „Strzelnica w powiecie” na dofinansowanie zadań zwiazanych $z$ budowa lub remontem strzelnic, https://trybun.org.pl/2018/08/30/mon-oglasza-konkurs-pn-strzelnica-w-powiecie-na-dofinansowanie-zadan-zwiazanych-z-budowa-lub-remontem-strzelnic.

Turczyn A., Organ (wójt, burmistrz, prezydent miasta) zatwierdzający regulamin strzelnicy nie jest uprawniony do badania innych kwestii niż sama treść regulaminu, https:// trybun.org.pl/2019/05/22/organ-wojt-burmistrz-prezydent-miasta-zatwierdzajacy-regulamin-strzelnicy-nie-jest-uprawniony-do-badania-innych-kwestii-niz-sama-tresc-regulaminu.

Turczyn A., Projekt rozporządzenia MON w sprawie dofinansowania z budżetu państwa zadań związanych $z$ budowa, remontami $i$ utrzymaniem strzelnic oraz rozwijaniem sportu strzeleckiego, https://trybun.org.pl/2018/04/18/projekt-rozporzadzenia-mon- 
-w-sprawie-dofinansowania-z-budzetu-panstwa-zadan-zwiazanych-z-budowa-remontami-i-utrzymaniem-strzelnic-oraz-rozwijaniem-sportu-strzeleckiego.

Turczyn A., Przełomowy wyrok sądu administracyjnego, który rozprawia się ze wszystkimi naruszeniami prawa $w$ sprawach o zatwierdzanie regulaminów strzelnic, https://trybun.org.pl/2018/01/03/przelomowy-wyrok-sadu-administracyjnego.

Turczyn A., Strzelnica padła ofiara walki politycznej, https://trybun.org.pl/2018/07/30/ strzelnica-padla-ofiara-walki-politycznej.

Zieliński J., sekretarz stanu w Ministerstwie Spraw Wewnętrznych i Administracji, Odpowiedź na interpelacje $n r 10011 \mathrm{w}$ sprawie wzorcowego regulaminu strzelnic, 14 marca 2017, http://www.sejm.gov.pl/Sejm8.nsf/InterpelacjaTresc.xsp?key=2AE714C2.

\section{Akty prawne}

Dyrektywa Parlamentu Europejskiego i Rady (UE) 2017/853 zmieniająca dyrektywę Rady 91/477/EWG w sprawie kontroli nabywania i posiadania broni, 17 maja 2017 r., Dz.Urz. UE L 137 z 2017 r., s. 22-39.

Ustawa z 21 maja 1999 r. o broni i amunicji, Dz.U. nr 53, poz. 549.

Ustawa z 9 września 2000 r. o podatku od czynności cywilnoprawnych, Dz.U. nr 86, poz. 959.

Ustawa z 27 marca 2003 r. o zmianie ustawy - Prawo budowlane oraz o zmianie niektórych ustaw, Dz.U. nr 80, poz. 718.

Rozporządzenie MSWiA z 15 marca 2000 r. w sprawie wzorcowego regulaminu strzelnic, Dz.U. nr 18, poz. 234.

\section{Orzecznictwo}

Wyrok WSA w Poznaniu z 25 października 2005 r., sygn. akt II SA/Po 2807/03, Legalis nr 2207003.

Wyrok WSA w Bydgoszczy z 21 listopada 2016 r., sygn. akt II SA/Bd 416/16, CBOSA. Wyrok WSA w Lublinie z 15 listopada 2017 r., sygn. akt III SA/Lu 216/17, LEX nr 2407704. Wyrok NSA z 24 stycznia 2018 r., sygn. akt II OSK 1462/17, LEX nr 2446376.

Wyrok WSA w Bydgoszczy z 24 stycznia 2018 r., sygn. akt II OSK 1462/17, LEX nr 2446376. Wyrok WSA w Szczecinie z 7 marca 2019 r., sygn. akt II SA/Sz 1108/18, CBOSA. Wyrok WSA w Rzeszowie z 27 marca 2018 r., sygn. akt II SA/Rz 66/18, LEX nr 2485969. Wyrok WSA w Szczecinie z 13 września 2018 r., sygn. akt II SA/Sz 216/18, CBOSA. Wyrok WSA w Gliwicach z 22 listopada 2018 r., sygn. akt IV SA/GI 797/18, LEX nr 2600526.

Wyrok WSA w Bydgoszczy z 19 grudnia 2018 r., sygn. akt II SA/Bd 971/17, CBOSA. Wyrok WSA w Gdańsku z 14 marca 2019 r., sygn. akt III SA/Gd 915/18, LEX nr 2650936. Wyrok WSA w Białymstoku z 17 października 2019 r., sygn. akt II SA/Bk 484/19, LEX nr 2738260.

Wyrok WSA w Lublinie z 17 października 2019 r., sygn. akt III SAB/Lu 28/19, CBOSA. Wyrok WSA w Kielcach z 13 lutego 2020 r., sygn. akt II SA/Ke 1117/19, CBOSA. 